\title{
INFLUÊNCIA DOS OVÓCITOS MADUROS VITELOGÊNICOS EM REABSORÇÃO NO DESENVOLVIMENTO MATURATIVO DO CARANGUEJO UCIDES CORDATUS (LINNAEUS, 1763) NA ILHA DO MARAJÓ/SOURE
}

\author{
Leal, C.A. ${ }^{1} ;$ Biancalana, A. ${ }^{1}$ \& Santos, A.K. ${ }^{1}$ \\ 1. Universidade Federal Do Pará (UFPA), Campus Soure, Laboratório de Biologia Celular e Molecular. \\ *Autor correspondente: cassianeazevedo19@gmail.com
}

O caranguejo Ucides cordatus é muito abundante no Norte e Nordeste do Brasil. Esses animais apresentam um grande teor proteico na carne, sendo bastante comercializada pela população local. Devido a sua extrema importância econômica, estudos relacionados à sua reprodução são importantes para o entendimento sobre a biologia da espécie. Os trabalhos realizados descrevem cinco estágios de desenvolvimento dos ovários do caranguejo Ucides cordatus, de acordo com a predominância dos tipos celulares encontrados. Durante o desenvolvimento algumas células apresentam constante vitelogênese, porém, a relação entre o processo de vitelogênese com desenvolvimento das gônadas ainda é pouco conhecida. Esse trabalho objetivou estudar o papel dos ovócitos maduros em degradação e reabsorção no desenvolvimento maturativo das gônadas do caranguejo-uçá. As coletas foram realizadas na Ilha do Marajó (Pará-Brasil), nas áreas de reserva Extrativista Marinha de Soure (RESEX). Foram capturados 292 caranguejos fêmeas, que posteriormente tiveram suas gônadas coletadas e processadas histologicamente. As análises realizadas permitiram a visualização de células ovarianas em diferentes estágios de maturação. Os ovócitos maduros, que não foram liberados para o processo de fecundação, apresentavam acúmulo de proteínas vitelínicas em forma de grânulos e estavam em processo de degradação e reabsorção. Associados a esses ovócitos estavam presentes zonas germinativas, que por vezes apresentavam-se dentro das células em reabsorção. Os resultados obtidos possivelmente indicam que a reserva proteica dos ovócitos tem possibilidade de ser utilizada no desenvolvimento de novas células germinativas, para diferenciação em novos ovócitos. Dessa maneira, é possível inferir que os ovócitos maduros em degradação e reabsorção podem influenciar no desenvolvimento maturativo das gônadas do caranguejo-uçá, auxiliando na proliferação de novas células, mostrando ser mais um elemento no processo de ovogênese.

Palavras-chave: Ucides cordatus, proteínas vitelínicas, ovócitos maduros. 